\title{
Fly populations associated with landfill and composting sites used for household refuse disposal
}

\author{
D. Goulson*, W.O.H. Hughes and J.W. Chapman \\ Division of Biodiversity and Ecology, School of Biological Sciences, \\ University of Southampton, Bassett Crescent East, Southampton, \\ SO16 7PX, UK
}

\begin{abstract}
Calyptrate fly populations were monitored with sticky traps at the following sites in Hampshire, UK during August to November 1998: a landfill and composting site (Paulsgrove), a site adjacent to this landfill (Port Solent), a site with no landfill nearby (Gosport), and a composting site with no landfill nearby. Overall, house flies Musca domestica (Linnaeus) and lesser house flies Fannia spp. were not important constituents of the dipteran catch, while bluebottles (Calliphora spp.) and greenbottles (Lucilia spp.) comprised approximately $12 \%$ of the total. Very large fly populations were found at the two composting sites, and it seems likely that these provide ideal breeding grounds for a range of fly species since they offer an abundance of warm decaying organic matter. Large fly populations were also evident at the landfill site. The suitability of household waste for the development of calyptrate Diptera was confirmed in a controlled trial: a mean of 0.43 adults emerged per kilo of one-week-old waste. Since many hundreds of tonnes of waste are delivered to the landfill daily, it is clear that the landfill is likely to substantially increase the local population of calyptrate flies. However, the data suggest that there was little movement of Diptera from the landfill to Port Solent situated approximately $500 \mathrm{~m}$ away. The most important calyptrate flies at this site were the cluster flies Pollenia rudis (Fabricius) and P. amentaria (Scopoli); the landfill site is unlikely to provide a suitable breeding site for these flies, as the larvae develop as parasites of earthworms. Significantly more flies emerged from oneweek-old than from two-week-old household waste. A comparison of different barriers to the emergence of adult house flies from waste demonstrated that sacking provided an effective barrier to fly emergence, but that soil did not differ significantly from control treatments. If managed appropriately, it seems that the use of sacking over landfill waste could substantially reduce associated fly populations.
\end{abstract}

\section{Introduction}

Calyptrate flies (Calyptratae), particularly species of Calliphoridae, Muscidae and Fanniidae, can be important vectors of human disease (Crosskey \& Lane, 1993). The propensity of the adults of many species to feed on human

*Fax: 01703594269

E-mail: DG3@soton.ac.uk food, as well as rubbish and excrement, gives them the potential for the mechanical transmission of pathogenic organisms (Crosskey \& Lane, 1993). Some calyprates also cause myiasis in humans and livestock (Hall \& Smith, 1993), and are intermediate hosts of parasitic nematodes attacking livestock (Snow, 1974). The annoyance and public health risks associated with large populations of such flies are thus considerable.

Human populations produce considerable quantities of waste with a large organic component suitable as a breeding 
site for many calyptrate fly species (Schoof et al., 1954; Siverly \& Schoof, 1955a,b; Wilton, 1961; Ikeda et al., 1972; Dirlbek, 1986; Ferriera \& Lacerda, 1993; Werner, 1997). The methods used for the disposal of household waste are likely to be crucial in determining the magnitude of associated fly problems, but apparently very little research has been performed in this area. Typical waste disposal procedure in the UK is as follows. Household waste is deposited in a container indoors which is emptied at erratic intervals into a larger outdoor receptacle. Commercial contractors then collect this at either weekly or fortnightly intervals. The waste is either taken directly to a disposal site or to a transfer station where it is deposited in piles for up to $24 \mathrm{~h}$. Most household waste is finally deposited in a landfill site. Here it is spread out in compacted layers using heavy machinery. At the end of the day the waste is traditionally covered in a $15 \mathrm{~cm}$ layer of soil to reduce odour, to prevent waste from blowing away, and to prevent animals such as seagulls and foxes from carrying waste from the site. More recently, many landfill sites in the UK have switched to using a hessian sacking (Geo Hess UK Ltd) to cover the waste at night. This has advantages in that it is quicker to lay down, and can be rolled up again in the morning. Use of a soil covering results in a substantial volume of the landfill being filled with soil rather than refuse. Given the shortage of landfill sites and the high cost of space within them, this is undesirable from economic and environmental viewpoints. Some household waste is also taken directly by the householder to waste recycling centres, where it is separated into categories such as glass, paper, organic matter or metal. The organic matter may then be taken to be composted, where it is allowed to rot for up to six months, shredded and sold as soil improver. In some regions, organic and inorganic waste is collected separately from each household in alternate weeks.

All stages of this process may have associated fly problems, as odours produced by organic waste will attract adult flies (Crosskey \& Lane, 1993). If the waste is managed inappropriately it can act as a breeding medium. Human refuse is known to be favourable for dipteran larval development for about one month after disposal (Wilton, 1961; Ikeda et al., 1972; Imai, 1984, 1985). Species which are particularly likely to be problematic in terms of human health include the housefly Musca domestica Linnaeus (Muscidae), the lesser housefly Fannia canicularis Linnaeus (Fanniidae), bluebottles Calliphora spp. (Calliphoridae) and greenbottles Lucilia spp. (Calliphoridae). These are synanthropic species, living in close association with humans. Musca and Fannia will develop in a range of decomposing matter, while Calliphora and Lucilia feed primarily upon animal matter as larvae (Colyer \& Hammond, 1968). However, there are many other species of medium to large fly which breed within organic matter and which may be regarded as pestiferous (Dirlbek, 1986; Ferriera \& Lacerda, 1993).

Restriction of larval breeding sites is thought to be the most effective way to control $M$. domestica populations (Eastwood et al., 1967; Keiding, 1974), not least because most populations are resistant to a range of insecticides (for example Yasutomi, 1966; Hayashi et al., 1977; Keiding, 1977; Chapman \& Morgan, 1992; Chapman et al., 1993). Fly problems associated with waste disposal sites have stimulated a small number of studies of the management options available. Pagano (1964) recommends covering waste with soil to prevent egress of emerging adult $M$. domestica. However Toyama (1988) found that even $25 \mathrm{~cm}$ of soil did not prevent $M$. domestica from escaping, and suggests that soil may only be useful as a means of preventing adults from laying further eggs in waste. Imai (1985) determined that the integration of several approaches could effectively suppress fly numbers at a landfill site in Japan. Mixing of waste with ash, covering of waste with $15 \mathrm{~cm}$ soil at weekly intervals, and spraying of insecticide when flies exceeded threshold levels achieved adequate control.

In October 1997 large fly populations were reported at Port Solent in Hampshire, UK where a landfill, composting site and recycling centre is situated within $500 \mathrm{~m}$ of a marina with houses, shops and restaurants. Large populations of flies (species unknown) entered the buildings in the marina (Environment Agency, personal communication).

The broad aims of this study were to examine management options that would minimize fly problems associated with household waste. Specifically, we: (i) identify which fly species are associated with household waste; (ii) compare fly populations associated with compost and landfill sites; (iii) compare fly numbers emerging from household waste collected at weekly versus fortnightly intervals; and (iv) compare hessian sacking and soil as barriers to emergence of flies developing in waste deposited in a landfill.

\section{Materials and methods \\ Monitoring of fly populations}

Fly populations were monitored using $40 \times 24.5 \mathrm{~cm}$ yellow sticky traps (Agrisense-BCS Ltd), a standard technique for studying fly distributions (Black \& Krafsur, 1985; Hogsette et al., 1993). These traps were hung at approximately $1 \mathrm{~m}$ above ground level at the following sites in Hampshire, UK: (i) The active landfill cell of Paulsgrove landfill, near Portsmouth (NGR634045, 51 ${ }^{\circ} \mathrm{N}$ ) (eight replicates); (ii) $50 \mathrm{~m}$ from this active cell (four replicates); (iii) Paulsgrove compost site (NGR633045) (four replicates); (iv) household waste recycling centre, Paulsgrove (NGR633046) (four replicates); (v) Port Solent (marina, restaurant and shop complex $500 \mathrm{~m}$ from the Paulsgrove landfill) (NGR633045) (four replicates); (vi) Gosport marina (a control site with no landfill nearby) (NGR612992) (four replicates); and (vii) Bushy Warren compost site, near Basingstoke (NGR653475) (four replicates).

During 1998, the waste deposited in the active cells at the landfill was covered with soil each day (rather than sacking). Monitoring traps were replaced at weekly intervals and were in use from 6 August 1998 to 14 September (sites 1-6) and from 1 October to 5 November (sites 1-7). The flies caught were categorized into the following taxonomic groupings: M. domestica, M. autumnalis De Geer (Muscidae), Fannia spp., Calliphora spp., Lucilia spp., Sarcophaga spp. (Sarcophagidae), Pollenia spp. (Calliphoridae), and other calyptrate Diptera. Differences in the total catch of calyptrate Diptera between sites were analysed using ANOVA on the mean catch per trap per week. Variation in numbers over time was analysed using a repeated measures ANOVA. A species list of pestiferous flies caught at the Paulsgrove active cell and the Bushy Warren compost site was compiled over the sample period. 


\section{Comparison of flies emerging from waste collected at one-week versus two-week intervals}

Waste samples were collected from the transfer station operated by Onyx Hampshire Ltd in Otterbourne, Hampshire on 6 August 1998. Waste was placed into black plastic dustbins with lids (cylindrical, $80 \mathrm{~cm}$ high by $60 \mathrm{~cm}$ diameter) to within $5 \mathrm{~cm}$ of the top. Samples were taken of waste collected at weekly and fortnightly intervals (ten replicates of each). The containers were stored outside at ambient temperature. Adult fly emergence was monitored using an emergence trap attached to the lid of each container; an $8 \mathrm{~cm}$ hole was cut in the lid and a clear plastic funnel inverted over the hole and glued in place. Flies attracted to the light would crawl up the inverted funnel and be caught within a clear plastic bottle over the end of the funnel. Fly emergence was monitored daily for 28 days. Flies were classified into the categories used above.

Differences in the numbers of flies emerging from oneweek-old and two-week-old waste were examined using a Kruskal-Wallis test. Separate tests were performed for each of the five categories of pestiferous fly that were recorded.

\section{Comparison of sacking and soil as barriers to fly emergence}

Fresh pupae of $M$. domestica were obtained from a culture held at the University of Southampton. Groups of 40 pupae were subjected to one of the following treatments within cylindrical plastic pots $(18 \mathrm{~cm}$ high and $10 \mathrm{~cm}$ diameter): (i) controls: pupae placed on the surface of $15 \mathrm{~cm}$ depth of damp soil; (ii) soil: pupae placed beneath $15 \mathrm{~cm}$ of damp soil; (iii) light grade sacking (dry): pupae were placed on $15 \mathrm{~cm}$ of damp soil as per controls, but then sealed beneath a layer of hessian sacking $\left(203 \mathrm{~g} \mathrm{~m}^{2}\right)$ held approximately $1 \mathrm{~cm}$ above them; (iv) light grade sacking (wet): as above but with the hessian sacking pre-soaked in water and kept wet throughout to simulate wet weather; (v) heavy grade sacking (dry): as (iii) but using $327 \mathrm{~g} \mathrm{~m}^{2}$ hessian sacking; and (vi) heavy grade sacking (wet): as (iv) but using $327 \mathrm{~g} \mathrm{~m}^{2}$ hessian sacking.

The hessian sacking was obtained from Geo Hess UK Ltd. Each treatment was replicated three times (720 pupae in

Table 1. Species composition and abundance of synanthropic Diptera caught on sticky traps (all sites combined).

\begin{tabular}{lcc}
\hline Species & $\begin{array}{c}\text { Number } \\
\text { of flies }\end{array}$ & $\begin{array}{c}\text { \% of total } \\
\text { catch }\end{array}$ \\
\hline House fly (Musca domestica) & 33 & 0.5 \\
Face fly (M. autumnalis) & 4 & 0.1 \\
Lesser house fly (Fannia spp.) & 32 & 0.5 \\
Bluebottle (Calliphora vomitoria + C. vicinia) & 534 & 7.5 \\
Greenbottle (Lucilia spp.) & 319 & 4.5 \\
Flesh fly (Sarcophaga spp.) & 81 & 1.1 \\
Cluster fly (Pollenia rudis + P. amentaria) & 84 & 1.2 \\
Other calyptrate Diptera & 6081 & 84.8 \\
Total & 7168 &
\end{tabular}

The following species were the most common in the category 'other calyprate Diptera', and are listed in order of decreasing abundance: Phaonia spp. (very abundant at composting sites), Polietes lardaria (Fabricius), Eustalomyia spp., Scathophaga stercoraria Linnaeus, Graphomyia maculata (Scopoli), Mesembrina meridiana (Linnaeus) and Neomyia cyanella (Meigen).
Table 2. Total catches of cluster flies (Pollenia spp.), and proportion of the total catch composed of cluster flies, at sticky traps in the Port Solent marina complex and the other sample sites (combined).

\begin{tabular}{lcc}
\hline Date & Port Solent marina & All other sites combined \\
\hline 8 Sept 98 & $19(42 \%)$ & $1(0.16 \%)$ \\
15 Sept 98 & $6(24 \%)$ & $3(1.1 \%)$ \\
08 Oct 98 & $3(19 \%)$ & $1(0.25 \%)$ \\
15 Oct 98 & $17(63 \%)$ & $4(0.58 \%)$ \\
22 Oct 98 & $26(74 \%)$ & $4(0.67 \%)$ \\
29 Oct 98 & 0 & $6(1.1 \%)$ \\
05 Nov 98 & 0 & $1(0.27 \%)$ \\
\hline
\end{tabular}

total). They were maintained at $25^{\circ} \mathrm{C}$ for ten days (adults take about five days to emerge). The proportion of flies that emerged and successfully penetrated the material was analysed in GLIM with binomial errors according to treatment.

\section{Results}

\section{Monitoring of fly populations}

In total, 7168 calyptrate flies were caught on sticky traps over the 11 sampling weeks. Overall very few $M$. domestica or Fannia spp. were caught (33 and 32, respectively), and none were recorded at the Port Solent or Gosport marinas. Catches of Calliphora spp. and Lucilia spp. were higher (534 and 319 , respectively), but the majority of flies caught were scattered among a broad range of genera (table 1).

Cluster flies (Pollenia spp.) were not recorded at any of the sites until 8 September; from this date until 22 October they were caught in relatively large numbers at Port Solent marina (table 2). They were the most important species at this site, comprising up to $74 \%$ of the total catch on 22 October. In contrast, they were very scarce at the other sites, never exceeding $1 \%$ of the total catch.

Total catches of all calyptrate flies varied considerably over time and between sites (fig. 1). Differences between sites were significant $(\mathrm{F}=3.60, \mathrm{df}=6,31, P=0.01)$, with catches at the two composting sites being consistently amongst the highest. Catches were generally lowest at the control site (Gosport) and at Port Solent (approximately $500 \mathrm{~m}$ from the landfill) and were highest at the two composting sites. There was also considerable variation between sample dates (repeated measures ANOVA, $F=3.90$, $\mathrm{df}=10,140, P<0.001)$ which may be attributable to variation in the weather or to genuine fluctuations in fly populations (fig. 1).

\section{Comparison of flies emerging from waste collected at one-week versus two-week intervals}

In total 142 flies emerged from the 20 containers, of which 59 belonged to the groups of calyptrate flies listed above. Of these 59 flies, more emerged from the one-week-old waste (49) compared with ten from the two-week-old waste (table 3). However, for four of the five categories there was no significant difference in the numbers of flies emerging from one-week-old and two-week-old waste, since numbers emerging from each replicate were highly variable. For the category 'other calyptrate Diptera' there were significantly more in the one-week-old sample of waste (table 3). 
Table 3. Comparison of the numbers of flies emerging from one-week-old versus two-week-old household waste samples $(\mathrm{n}=10)$.

\begin{tabular}{llllll}
\hline & $\begin{array}{l}\text { Musca } \\
\text { domestica }\end{array}$ & $\begin{array}{c}\text { Fannia } \\
\text { spp. }\end{array}$ & $\begin{array}{l}\text { Calliphora } \\
\text { spp. }\end{array}$ & $\begin{array}{l}\text { Lucilia } \\
\text { spp. }\end{array}$ & $\begin{array}{l}\text { Other } \\
\text { calyptrates }\end{array}$ \\
\hline Weekly & 4 & 3 & 6 & 8 & 27 \\
Fortnightly & 0 & 1 & 4 & 3 & 2 \\
Chi square & 3.33 & 0.45 & 0.06 & 0.51 & 4.59 \\
Df & 1 & 1 & 1 & 1 & 1 \\
$P$ & 0.07 & 0.50 & 0.80 & 0.80 & $0.03^{*}$ \\
\hline
\end{tabular}

*P<0.05

Chi-square statistics are from Kruskal-Wallis tests performed on each taxonomic grouping.

There is little in the way of clear patterns in the timing of emergence, with small numbers of both pestiferous and other flies emerging throughout the four weeks of the experiment.

In total $243 \mathrm{~kg}$ of waste was collected, $114 \mathrm{~kg}$ of oneweek-old and $129 \mathrm{~kg}$ of two-week-old. This equates to 0.43 flies emerging per kilo from one-week-old waste and 0.08 from two-week-old waste (mean 0.26).

\section{Comparison of sacking and soil as barriers to fly emergence}

Emergence of control pupae was high (92.5\%). Soil acted as a poor barrier to penetration, with $85 \%$ of flies successfully emerging, a result that did not differ significantly from the control. In total only one fly emerged from all four treatments involving sacking, of a total possible of 480 (table 4$)$. This difference is highly significant $\left(\chi^{2}=699\right.$, $\mathrm{df}=5, P<0.001$ ), demonstrating that both grades of sacking provided an effective barrier to fly penetration, whether wet or dry.

\section{Discussion}

The proportion of $M$. domestica found emerging from samples of waste and trapped on the monitoring sticky traps at or near the landfill site was low, suggesting that this species was not an important component of the fly population, at least during the time period of this study. This is unexpected, as most previous studies of flies associated with household waste in other countries reported high numbers of M. domestica (Imai, 1984, 1985; Eesa \& El Sibae, 1993). However, Ikeda et al. (1972) reported low proportions of $M$. domestica in flies emerging from garbage in Hawaii. In common with other studies of flies associated with waste disposal sites (for example Dirlbeck, 1986; Werner, 1997), numerous other species of large fly were found in abundance, including synanthropic pest species such as bluebottles (Calliphora spp.), and greenbottles (Lucilia spp.). Samples of waste collected at fortnightly intervals appeared to contain fewer developing flies than waste collected at weekly intervals. This may be because many adult flies had

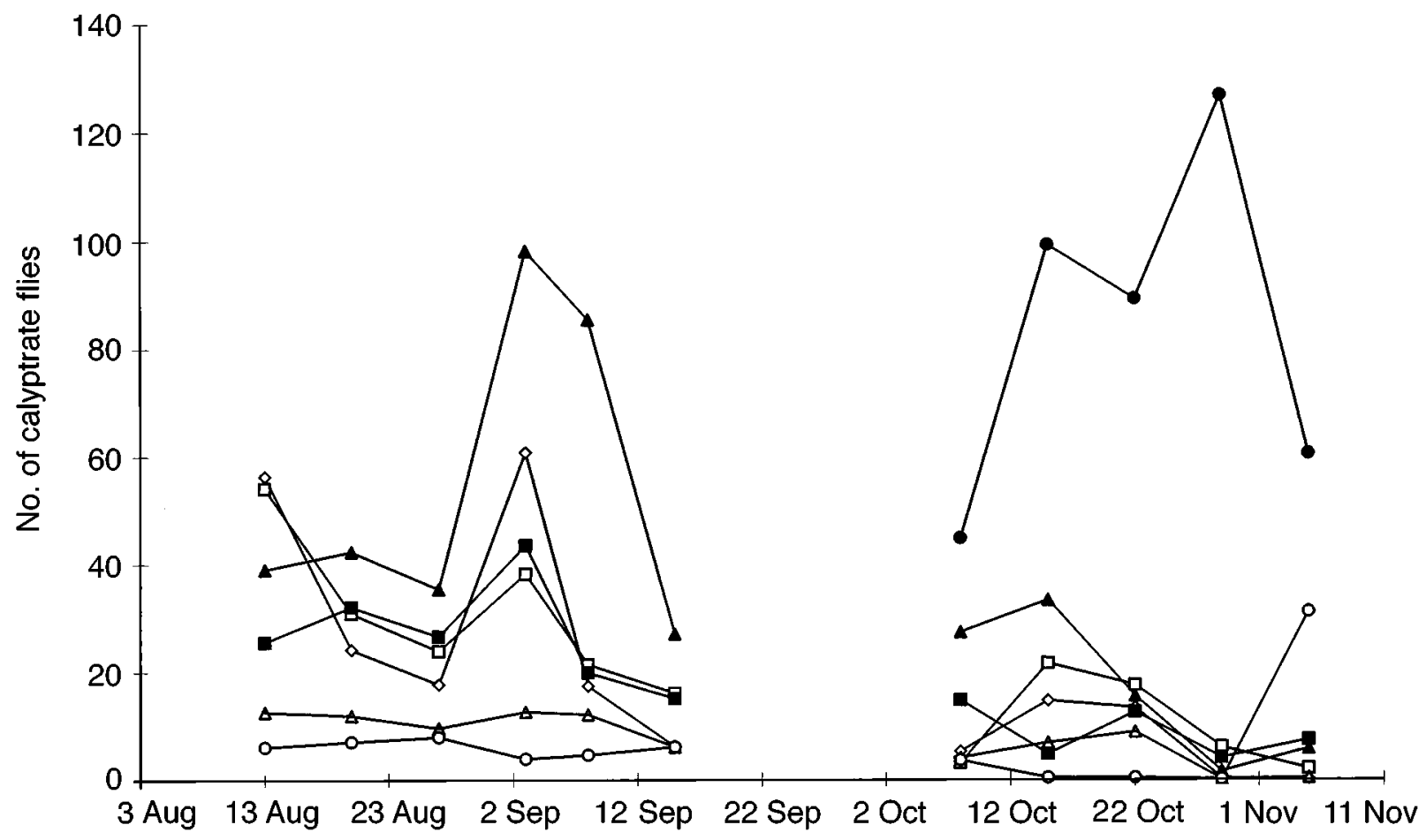

Fig. 1. Mean catch of calyptrate Diptera per week at each of seven sites: $\diamond$, Paulsgrove active cell; $\boldsymbol{\Lambda}$, Paulsgrove compost; $\triangle$, Port Solent; $\boldsymbol{0}$, Bushy Warren compost; $\square$, Paulsgrove $50 \mathrm{~m}$ from active cell; $\mathbf{\square}$, Paulsgrove recycling centre; $\bigcirc$, Gosport. Means are based on four traps per site: except at the active cell where eight traps were used. Trapping was carried out from 6 August until 5 November 1998 , with a gap between 14 September and 1 October. Catches are marked at the end of each week of trapping. 
Table 4. Percentage penetration of two grades of hessian sacking (wet and dry), and $15 \mathrm{~cm}$ of soil, by emerging adult house flies.

\begin{tabular}{lcc}
\hline & Penetration $(\%)$ & SD \\
\hline 203 g, dry & 0.00 & 0.00 \\
203 g, wet & 0.83 & 1.13 \\
327 g, dry & 0.00 & 0.00 \\
327 g, wet & 0.00 & 0.00 \\
Soil & 85.0 & 8.97 \\
Control & 92.5 & 5.18 \\
\hline
\end{tabular}

Means of three replicates \pm 1 SD.

already emerged from the older waste before it was collected; certainly many species can complete development within one week given favourable conditions (Skidmore, 1985). However, emergence was highly variable between replicates, presumably due to the infrequent inclusion of large items of organic waste to which a gravid female fly had gained access. Overall numbers of flies emerging were small, so we cannot be confident that waste collected at fortnightly intervals would consistently produce fewer adult flies.

Monitoring with sticky traps indicated that flies were particularly abundant in the proximity of the two composting sites throughout the sampling periods. Fly abundance remained high at the Bushy Warren site until late in the autumn when adult fly activity at the other sites was much lower. Composting sites clearly provide an abundance of breeding material for fly species whose larvae live in organic matter, and the material remains warm throughout the year (Werner, 1997). The larvae of many Muscidae feed primarily on bacteria involved in fermenting rotting matter (Skidmore, 1985). Accumulations of organic matter associated with livestock rearing units regularly precipitate fly population outbreaks which threaten human and animal health (Axtell, 1970; Howard \& Wall, 1996). Although composting of organic matter is desirable from an ecological perspective, it seems probable that composting sites are a source of pestiferous flies and that they may contribute substantially to fly infestations experienced by people living nearby. Where possible it makes sense to locate these sites as far as possible from human habitations since flies readily disperse from breeding sites (Imai, 1984; Lysyk \& Axtell, 1986). Alternatively, the composting material could be covered in sacking.

Fly populations were also high in the proximity of the landfill active cell compared with the two sites (Gosport and Port Solent) which were not immediately adjacent to waste disposal facilities. Clearly adult flies do emerge from the household waste deposited in the landfill, as demonstrated by emergence from samples of waste (0.08-0.43 flies per kg). The weight of waste deposited per day varies greatly, but is of the order of $100->1000$ tonnes. Extrapolating from our results, and assuming that no measures were taken to prevent flies emerging from the waste, 100 tonnes will result in 8000-43,000 flies emerging from the landfill. Other studies have also found substantial production of flies from human waste. For example Brown et al. (1970) report up to 30,150 Phaenicia (Lucilia) spp. emerging from single household garbage containers in California. In Japan, Imai (1984) found that 1300-1500 flies emerged per $\mathrm{m}^{2}$ of landfill surface in one month following deposition. The presence of a $25 \mathrm{~cm}$ layer of bulldozer compacted soil over the surface of the waste did little to reduce fly emergence (Toyama, 1988), in accordance with our own study. If soil barriers are ineffective then landfills such as that at Paulsgrove must substantially enhance local fly populations. Use of sacking as an alternative covering appears to have advantages over soil in that it could provide an impermeable barrier to emerging flies. However, since normal practice is to roll the layer of sacking back each morning to allow deposition of fresh waste, any flies which emerge will be regularly released. In addition, the layer of sacking is often damaged by heavy machinery moving over it (D. Goulson, personal observation), which will also enable flies to escape. At present, neither soil nor sacking provides an effective barrier to emergence of flies from waste in landfills. If management practices were changed so that layers of sacking were left down permanently and care was taken not to damage this layer, then sacking could substantially reduce fly emergence from waste.

Although large fly populations were in evidence at the Paulsgrove landfill site, catches of pestiferous Diptera at the Port Solent marina complex (500 $\mathrm{m}$ from the landfill) remained relatively low throughout the sample period, and similar in scale to numbers at the control site. This suggests that there was little movement of Diptera from the landfill to the marina, at least during the duration of our study. The majority of calyptrate Diptera caught at the Port Solent site during the latter part of the study were cluster flies Pollenia rudis (Fabricius) and P. amentaria (Scopoli) (Calliphoridae), which comprised up to $74 \%$ of the total catch. Although cluster flies are not likely to be important vectors of disease, they may be problematic since the adults hibernate gregariously in buildings. When these buildings are restaurants or shops this is particularly undesirable. The biology of Pollenia spp. is poorly known, but they are thought to have only one generation per year and the larvae probably develop as parasites inside earthworms (Rognes, 1991; Will, 1995). In a very thorough study Werner (1997) found no Pollenia spp. emerging from rubbish tips in Germany. Hence, landfill sites are unlikely to provide a suitable breeding site for these species.

\section{Acknowledgements}

This work was funded in part by Onyx Hampshire Ltd.

\section{References}

Axtell, R.C. (1970) Integrated fly-control program for cagedpoultry houses. Journal of Economic Entomology 63, 400-405.

Black, W.C. \& Krafsur, E.S. (1985) Use of sticky traps to investigate seasonal trends in the spatial distribution of house flies and stable flies (Diptera: Muscidae). Journal of Medical Entomology 22, 550-557.

Brown, P., Wong, W. \& Jelenfy, I. (1970) A survey of the fly production from household refuse containers in the city of Salinas, California. California Vector Views 17, 19-28.

Chapman, P.A. \& Morgan, C.P. (1992) Insecticide resistance in Musca domestica L. from eastern England. Pesticide Science 36, 35-45.

Chapman, P.A., Learmount, J., Morris, A.W. \& McGreevy, P.B. (1993) The current status of insecticide resistance in Musca domestica in England and Wales and the implications for housefly control in intensive animal units. Pesticide Science 39, 225-235. 
Colyer, C.N. \& Hammond, C.O. (1968) Flies of the British Isles. $384 \mathrm{pp}$. London, Frederick Warne \& Co. Ltd.

Crosskey, R.W . \& Lane, R.P. (1993) House-flies, blowflies and their allies (calyptrate Diptera). pp. 403-428 in Lane, R.P. \& Crosskey, R.W. (Eds) Medical insects and arachnids. London, Chapman and Hall.

Dirlbek, K. (1986) Fauna of Diptera on refuse depositions on communal waste in Prague. Casopis Narodniho Muzea v Praze Rada Prirodovedna 155, 160-172.

Eastwood, R.E., Kada, J.M., Schoenburg, R.B. \& Brydon, H.W . (1967) Investigation on fly control by composting poultry manures. Journal of Economic Entomology 60, 88-98.

Essa, N.M. \& El Sibae, M.M. (1993) Population dynamics of some synanthropic fly species in different habitats in Buraydah Saudi Arabia. Journal of the Egyptian Society for Parasitology 23, 133-140.

Ferriera, M.J.D.M. \& Lacerda, P.V.D. (1993) Synanthropic muscoids associated with the urban garbage in Goiania, Goias. Revista Brasileira de Zoologia 10, 185-195.

Hall, M.J.R. \& Smith, K.G.V. (1993) Diptera causing myiasis in man. pp. 403-428 in Lane, R.P. \& Crosskey, R.W. (Eds) Medical insects and arachnids. London, Chapman and Hall.

Hayashi, A., Funaki, E., Fuzimagari, M., Kano, R. \& Nomura, K. (1977) The resistant level of the housefly to several synthetic insecticides in west of Kanto and Kyushu, Japan. Botyu-Kagaku 42, 198-203.

Hogsette, J.A., Jacobs, R.D. \& Miller, R.W. (1993) The sticky card: device for studying the distribution of adult house fly (Diptera: Muscidae) populations in closed poultry houses. Journal of Economic Entomology 86, 450-454.

Howard, J.J. \& Wall, R. (1996) Control of the house fly, Musca domestica, in poultry units: current techniques and future prospects. Agricultural Zoology Reviews 7, 247-265.

Ikeda, J.K., Watanabe, W.H., Totama, G. \& Shimoda, L. (1972) Effects of plastic bags as refuse containers on fly populations. Proceedings of the Hawaiian Entomological Society 21, 225-234.

Imai, C. (1984) Population dynamics of houseflies Musca domestica on experimentally accumulated refuse. Researches on Popululation Ecology (Kyoto) 26, 353-362.

Imai, C. (1985) A new method to control houseflies Musca domestica at waste disposal sites. Researches on Popululation Ecology (Kyoto) 27, 111-124.

Keiding, J. (1974) Houseflies, Musca domestica. pp. 5-30 in Pal, R. \& Wharton, R.H. (Eds) Control of arthropods of medical and veterinary importance. New York, Plenum.

Keiding, J. (1977) Resistance in the housefly in Denmark and elsewhere. pp. 261-302 in Watson, D.L. \& Brown, A.W.A.
(Eds) Pesticide management and insecticide resistance. London, Academic Press.

Lysyk, T.J. \& Axtell, R.C. (1986) Movement and distribution of house flies (Diptera: Muscidae) between habitats in two livestock farms. Journal of Economic Entomology 79, 993-998.

Pagano, S. (1964) Sanitary landfill operations in New York State. Public Health Reports 79, 543-548.

Rognes, K. (1991) Blowflies (Diptera: Calliphoridae) of Fennoscandia and Denmark. Fauna Entomologica Scandinavica 24, $272 \mathrm{pp}$.

Schoof, H.F., Mail, G.A. \& Savage, E.P. (1954) Fly production sources in urban communities. Journal of Economic Entomology 47, 245-253.

Siverly, R.E. \& Schoof, H.F. (1955a) Utilization of various production media by muscoid flies in a metropolitan area. I. Adaptability of different flies for infestation of prevalent media. Annals of the Entomological Society of America 48, $258-262$.

Siverly, R.E. \& Schoof, H.F. (1955b) Utilization of various production media by muscoid flies in a metropolitan area. II. Seasonal influence on degree and extent of fly production. Annals of the Entomological Society of America 48, 320-324.

Skidmore, P. (1985) The biology of the Muscidae of the world. Dordrecht, Dr W. Junk Publishers.

Snow, K.R. (1974) Insects and disease. London, Routledge \& Kegan Paul Ltd.

Toyama, G.M. (1988) A preliminary survey of fly breeding at sanitary landfills in Hawaii USA with an evaluation of landfill practices and their effect on fly breeding. Proceedings of the Hawaiian Entomological Society 28, 49-56.

Werner, D. (1997) Die Depterofauna verschiedener Mülldeponien und Kompostierungsanlagen in der Umgebung von Berlin unter besonderer Berücksichtigung ihner Ökologie und Bionomie. Studia Dipterologica Supplement 1, $176 \mathrm{pp}$.

Will, K.W. (1995) Overwintering of Pollenia rudis (Diptera: Calliphoridae). Entomological News 106, 177.

Wilton, D.P. (1961) Refuse containers as a source of flies in Honolulu and nearby communitites. Proceedings of the Hawaiian Entomological Society 17, 477-481.

Yasutomi, K. (1966) Insecticide resistance of houseflies outbroken at the dumping site, Yumenoshima island, Tokyo. Japanese Journal of Sanitary Zoology 17, 71-73.

(Accepted 24 September 1999) (C) CAB International, 1999 